\title{
キャビテーション発光と壊食*
}

田部井 勝 稲 ${ }^{* *}$ 天 谷 賢 児**

\section{Cavitation Light Emission and Cavitation Erosion}

\author{
By Katsuine Tabei** Kenji Amagai**
}

Cavitation bubbles emit a very weak light due to bubble collapse. It is expected that the light emission may be closely related to cavitation erosion. In order to confirm the relationship between the erosion damage rate and the light intensity, experiments were performed for a water orifice cavitation flow. A circular pipe was used and water-cavitation generated around a column. For the measurement of light intensity, photon-counting method was used. And for visualization, the xenon gas-mixing method was adopted this by use of an image intensifier and chilled CCD camera. The damage rate was estimated by counting the number of damage pits. The light emission occurred around the end of cavitation, but the emission pattern was very different from the shape of the cavitation. The profile of the damage area was very similar to the light emission pattern and the maximum damage rate had a strong relationship with the maximum emission intensity.

\section{1. まえがき}

キャビテーションをともなう流れ場は, 多数の気泡 が短時間に発生と消滅を繰り返す非常に複雑な気液混 相流であり，流体機械に壊食や騒音を引き起こす。こ のため壊食位置と壊食度を知るのは流体機械の安全性 を確保する上でも極めて重要である。この壊食位置は キャビテーション気泡群の様子から，ある程度推定で きるが，必ずしも正確ではない，壊食度については実 機や模型を使って実験的に求めるのが一般的であるが, 実験には長い時間を要するのが難点である，また，現 在のところ，このようなキャビテーション流れに関す る数值解析は，十分な精度が得られていないのが実状 である. CFDにより浮遊気泡が物体表面で崩壊し, そ の衝撃圧で塑性変形する壊食ピットを見積る研究(1)も 始まってはいるが，キャビテーション現象の解明には 実験的な方法に頼らざるを得ない部分が多い.

一方，キャビテーションの発生位置では強い気泡の 収縮に伴い, 発光現象の起こることが知られている. この発光位置は, 強いキャビテーション気泡の崩壊が 生じている位置を示すだけでなく, 発光強度が崩壊の 強さに関連していると考えられる. したがって, キャ ビテーション発光を観察することで, 壊食位置や壊食 度をある程度推定できる可能性がある。このような観 点から, 著者らはキャビテーション発光と壊食特性の 関連性について研究を行ってきた (2)- (7). 本解説ではキ ヤビテーション発光の概要を述べるとともに, その応 用について述べることにする.

\section{2. 発光と壊食}

* 原稿受付 平成 19 年 10 月 22 日

** 群馬大学大学院工学研究科機械システム工学専攻 （群馬県桐生市天神町 1-5-5）
キャビテーションの発生は物体表面に損傷を与える 壊食現象とともに, 非常に微弱な発光現象を伴うこと が多い. 壊食は気泡が壁面近傍で崩壊する際に生じる マイクロジェットや衝撃波の高衝撃圧力（数百気圧以 上）によって引き起こされる材料の塑性変形であり, その進展によって疲労破壊が生じる ${ }^{(8),(9)}$. 一方, キャ ビテーション発光（ルミネッセンス）の研究の歴史は 比較的古く, 約半世紀にわたる膨大な研究がある.た だし，これらは超音波キャビテーションでの研究が主 であり, 流れ場でのキャビテーション発光に関する研 究は非常に少なく, いまだ完全には解明されていない.

流水中のキャビテーション形態は気泡, シート, ク ラウド，渦キャビテーションの混成した複雑なもので あり, 発光現象は超音波によるソノルミネッセンス ${ }^{(10),}$ (11)のように単純（球形気泡の仮定）ではないと思われ る. 超音波キャビテーション研究から, 発光原因とし ては水蒸気気泡の収縮時の断熱圧縮による熱化学反応 によるものとする説（ホットスポット説）が有力であ るが(12)-(15), 他にも気泡内衝撃波の集中による高温化説 (10)もある.

キャビテーション壊食, および, キャビテーション 発光は，いずれもキャビテーション気泡の崩壊が関係 しているために，両者には強い相関関係があると考え られる. 両者の相関性が明確になれば，発光の検知は キャビテーションによる壊食の領域，規模を推定する のに極めて有益な方法となりうる. すなわち，長時間 の壊食実験を行なわなくても，これらの特性をごく短 時間で見積もれる可能性がある。これは複雑な機械に なるほど有利である.

発光と壊食の相関性については，これまで二次元水

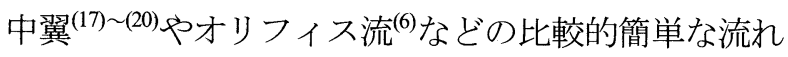
場でのみ研究が行われ, 複雑な流れ場での発光の研究 
は行われてこなかった。これは，キャビテーション発 光の発光時間が $100 \mathrm{ps}$ 以下と極めて短時間で, 発光強 度も極微弱であること，さらに，壊食試験片の取り付 けが構造上困難な場合が多いためと推察される. しか しながら，今後このキャビテーション発光を用いた壊 食特性の推定技術が確立すれば，より複雑な流体機械 への応用も期待できる.

\section{3. 発光の計測法}

キャビテーション発光は，通常肉眼では確認できな いほどに極微弱なもので，計測にある程度の工夫が必 要である. 発光の確認, 定量計測にはフォトンカウン ターを利用するのがよい．計測点からの光をなるべく 大きな集光レンズで集め, 検出管入射部に焦点を結ば せる. $10^{-6} \mathrm{Lx}$ 程度の照度でも検出できるようにするの が望ましい. また，このようなフォトンカウンターの 計測では，通常ピンポイントの計測となる. 発光の全 体像を知るためには，二次元光子計数管を用いればよ いが，高価である.

安価に実験を行うためには，発光自身を増強して可 視化する方法が取られる(20). これにはキセノン混入法 やルミノール・炭酸ソーダ法などが考案されている. 特に, キセノンは水への溶解度が高く, 一度水に溶け ると簡単には脱気しないために, キセノン混入法のほ うが利用しやすい. 炭酸ソーダ法はソーダの混入量が 多いために，実験後の水処理に難点がある. また，機 械内を循環するうちにキャビテーションでルミノール が分解されるためか強度が徐々に弱くなる傾向がある。 このように増強しても発光強度の増加は数十倍から数 百倍であり，条件にもよるが，肉眼でかろうじて明滅 する光点群を確認できる程度である. そこで可視化の ためにはさらに冷却 CCD カメラよる長時間露光や, イメージインテンシファイアに通常のデジタルカメラ を取り付けて長時間露光する必要がある. 露光時間は 条件にもよるが, $10 \mathrm{~s}$ から $5 \mathrm{~min}$ 程度となる場合が多い.

\section{4. オリフィス流}

二次元水中翼周りに発生するキャビテーションから の発光と壊食の関係については, Meulen による先駆的, 系統的な研究(16),(17)が有名であるが，本解説では，著者 らがこれまでに行ってきたオリフィス流と物体の後流 に発生するキャビテーションにおける発光現象 ${ }^{(6),(7)}$ ついて述べることにする.

オリフィスのキャビテーション気泡は，エッジ部分 から発生し, オリフィス板直後の低圧領域で成長して 下流の圧力回復領域で崩壊するという過程をたどる.
図 1 はこのようなオリフィスキャビテーションの実験 装置を示している. 本実験装置は回流式となっており, 供試液体には水道水を用いた. タンク内の水はポンプ により加圧され，試験区間に流入する．試験区間に流 入した水はオリフィスキャビテーションを発生させ, もとのタンクに戻る. オリフィス上流圧はポンプの吐 出バルブにより調節している．下流圧は大気圧一定と

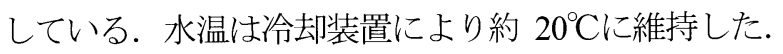
実験は上流圧 $P_{1}$ を変化させて行った. オリフィス部の 詳細を図 2 に示す．管内径 $D$ は $16.0 \mathrm{~mm}$, オリフィス 口径 $d$ は $7.0 \mathrm{~mm}$ である. 壊食状況を調べるために，一 辺 $2 \mathrm{~mm}$ の純銅製の角ロッドを管中心軸上に設置した. 壊食実験後に，オリフィスからの距離 $X$ における金属 表面の様子を顕微鏡撮影し，壊食傷（ピット）の数と 大きさを測定した. キャビテーション係数 $k$ はオリフ イス後の圧力 $P_{2}$ から次式により求めている.

$$
k=\frac{2\left(P_{2}-P_{v}\right)}{\rho V^{2}}
$$

ここで， $V$ はオリフィス部の平均流速， $\rho$ は密度， $P_{v}$ は水の飽和蒸気圧である.

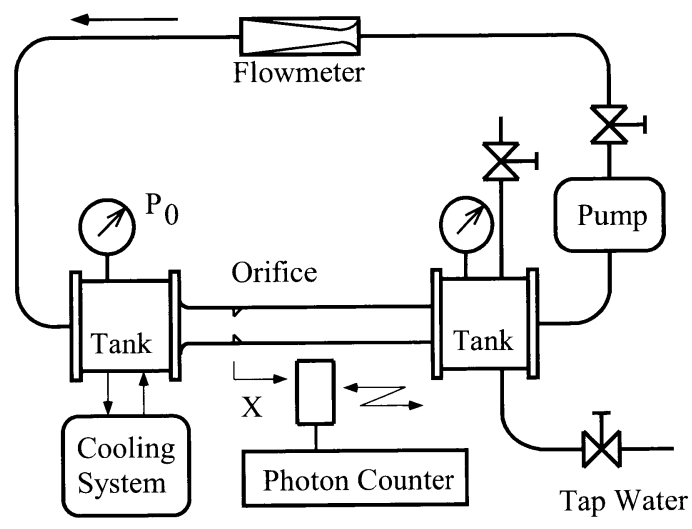

図 1 実験装置

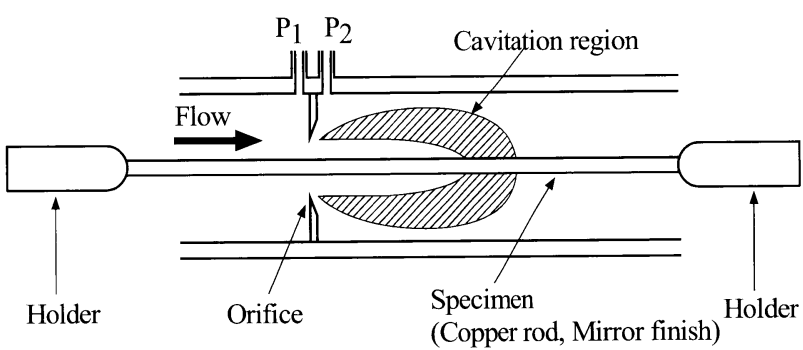

困 2 オリフィス部の詳細

図3は代表的なオリフィスキャビテーションのス トロボ写真である. 上流压 $P_{1}$ が増すにつれてキャ ビテーション気泡群が発達する様子がわかる.ここ では気泡群と発光パターンを見るために冷却 CCD カメラ（露光時間 $300 \mathrm{~s}$ ）での計測例を示す. 発光 


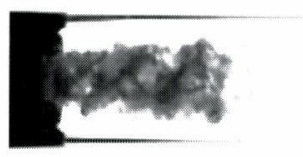

(a) $P_{1}=400 \mathrm{kPa}$

Ordinary cavitation

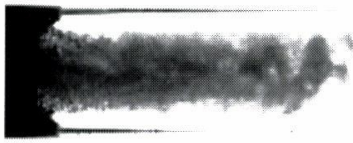

(b) $P_{1}=450 \mathrm{kPa}$

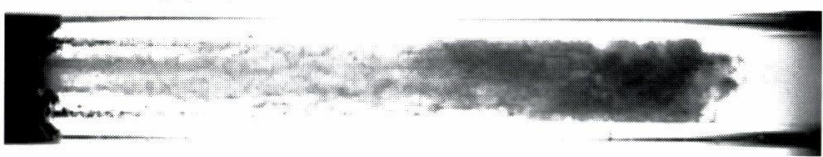

(c) $P_{1}=500 \mathrm{kPa} \quad$ Jet flow with a large cavity

図3 オリフィスキャビテーション

$(d=7 \mathrm{~mm}, D=16 \mathrm{~mm})$

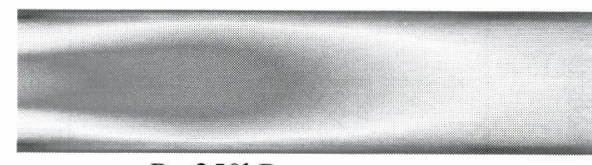

$P_{1}=350 \mathrm{kPa}$
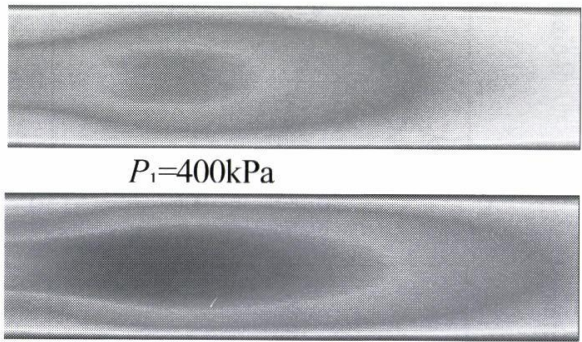

$P_{1}=450 \mathrm{kPa}$

(a) キャビテーション気泡群による光透過率パターン

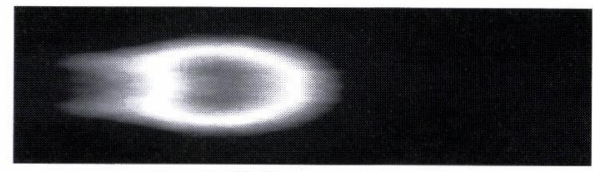

$P_{1}=350 \mathrm{kPa}$

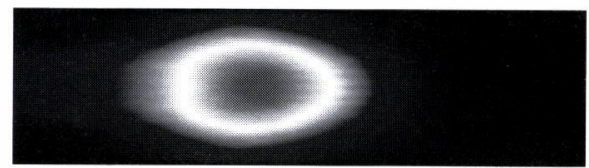

$P_{1}=400 \mathrm{kPa}$

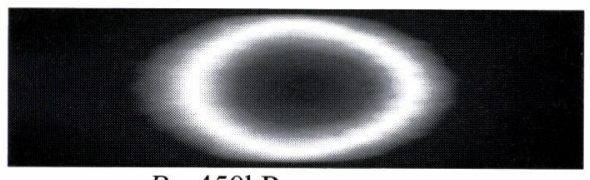

$P_{1}=450 \mathrm{kPa}$

(b) キャビテーション発光強度分布

図4 キャビテーション気泡と発光

を可視化するために，キセノンガス $(\mathrm{Xe})$ を覺䢁器によ り体積濃度で $3 \%$ 程度混入している。

図4(a)は, LEDの弱 背景光ごしに測定したキャビテ ーション気泡群による光の透過率パターンを示してい る. また，図4(b)は管外からタたキャビテーション発光
強度分布を示したものである. キャビテーション発光は 明らかに気泡群の消㓕寸る付近で強いことが分かる。こ れらの図は管外から見たときの積分強度であるので，こ れらを CT 手法のひとつである気泡群による減光を考慮 したアーベル変換(4),(5)を施すと図5 の結果が得られる.

図 5(a)はいわば気泡群の濃度を示し，図 5(b)は管断面 内の放射光強度を示している. キャビテーションはオリ フィスエッジ部から発生していることが明瞭にわかる. 発光も気泡群濃度の影響を受けているが, 最大強度付近 のパターンは変換前とそれほど変わらない，強度は加圧 力 $P_{1}$ が増すと共にオリフィスから離れたところで強く なる傾向にある. キャビテーションの影絵写真と比較す ると, 気泡群の少なくなる圧壊領域,つまり圧力回復領 域で発光していることがわかる.

図6は管中心軸上の発光強度分布を示したものである. 加圧力の増大とともに発光強度が増寸こと, 最大発光位 置が下流側に移動することがわかる。

例として $P_{1}=400 \mathrm{kPa}, X=75 \mathrm{~mm}$ の位置での壊食実験 における銅表面の金属顕微鏡写真 (CCD 画像) を図7 に示す. 撮影領域は500 $\mu \mathrm{m} \times 500 \mu \mathrm{m}$ であり, 図7 (a) は

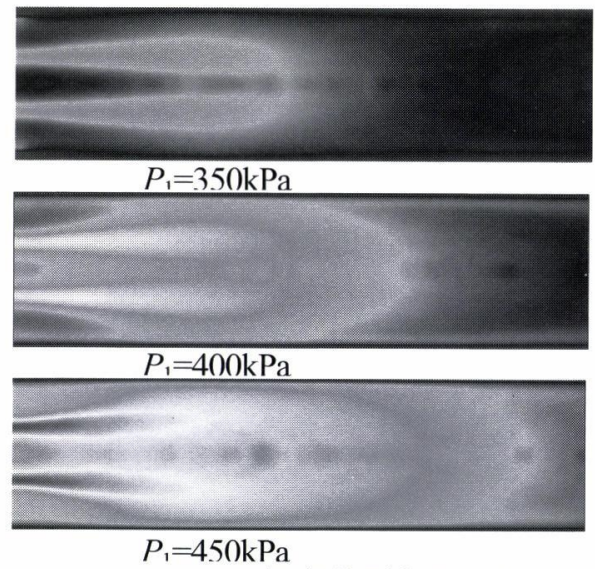

(a) キャビテーション気泡群の管断面濃度パターン
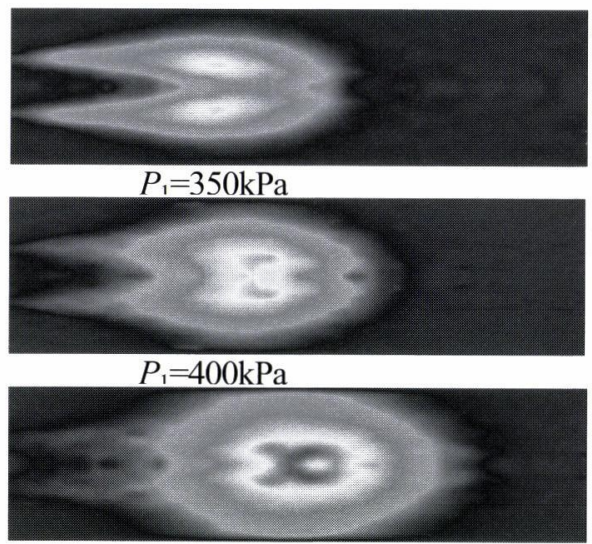

$$
P_{1}=450 \mathrm{kPa}
$$

(b) キャビテーション発光の管断面内の放射強度

図5 キャビテーション気泡と発光の管断面分布 
実験前を，図 7 (b) は実験後をそれぞれ示している．数 $\mu \mathrm{m}$ から数 $10 \mu \mathrm{m}$ までの壊食ピットが見られる. 図 7 (c) はその画像処理例である。

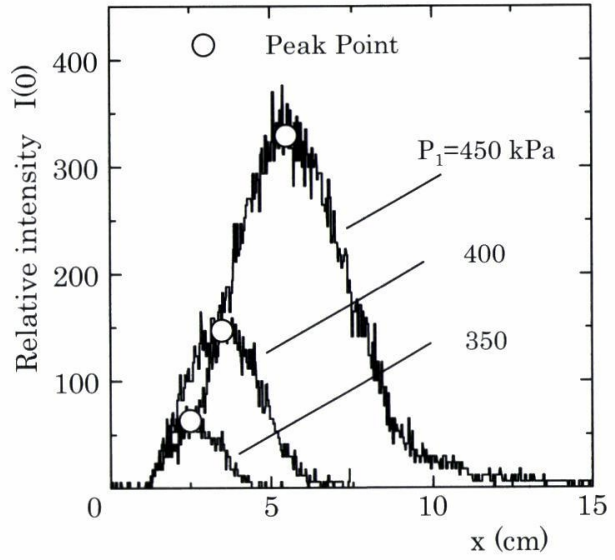

図6 管中心軸上の発光強度分布

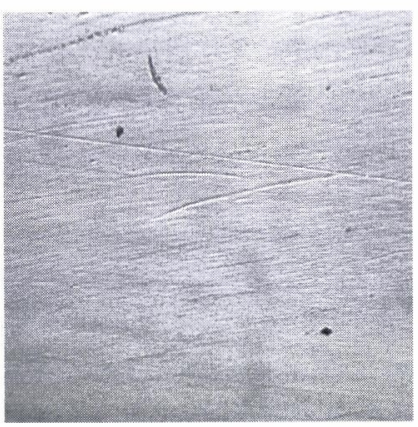

(a) 壊食試験前

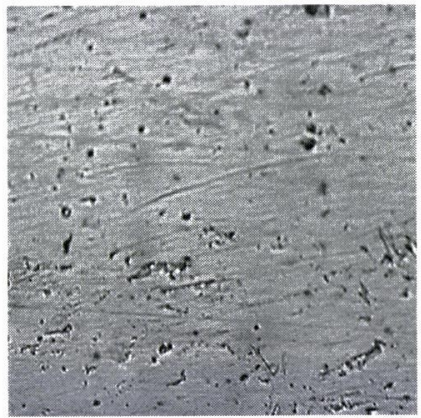

(b) 壊食試験後

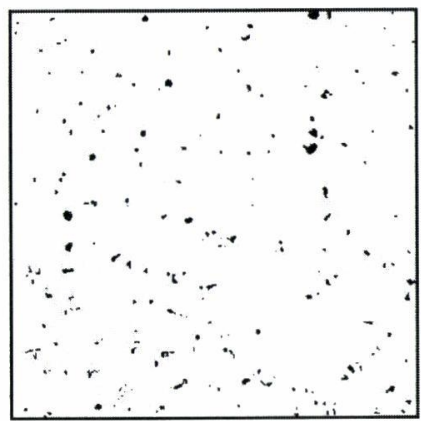

(c) 画像(b)の処理画像

図 7 銅表面の顕微鏡写真
壊食ピット直径 $D_{p}$ が $4 \mu \mathrm{m}$ 以上 $10 \mu \mathrm{m}$ 末満のピット の総数から，壞食速度を単位面積単位時間当たりに形 成されるピット数 $a_{1}\left(\mathrm{pits} / \mathrm{cm}^{2} \mathrm{~s}\right)$ で定義した. オリフィ スからの距離 $X$ に対寸る壊食速度分布 $a_{1}$, 相対発光強 度分布 $I$ ，および，壁面平均圧力分布 $P_{w}$ の変化を図 8 (a) 〜図 8(d) に示す.

壊食速度分布は発光強度分布とやや位置がずれ, 加 圧力 $P_{1}$ が増すほど, 寸なわち流速が増すほど壞食速度 分布は発光分布より下流側にシフトする傾向が見られ た.これらを管壁圧力分布と比較寸ると, 発光は圧力 回復領域の前半で強く, 壊食速度は圧力回復時の後半 で大きいことがわかる. 発光は圧力回復領域の流れ場 全体で生じ，一方，壞食は物体近傍の崩壊気泡により
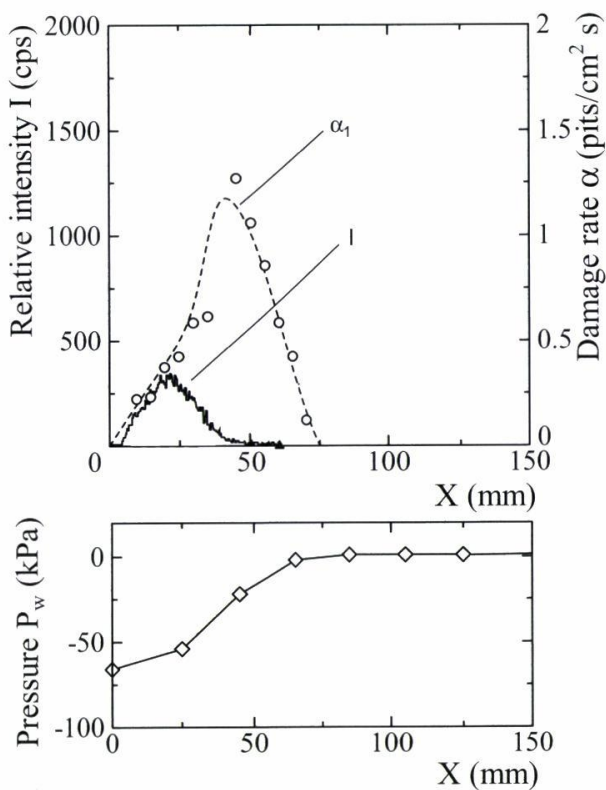

(a) $P_{I}=300 \mathrm{kPa}$
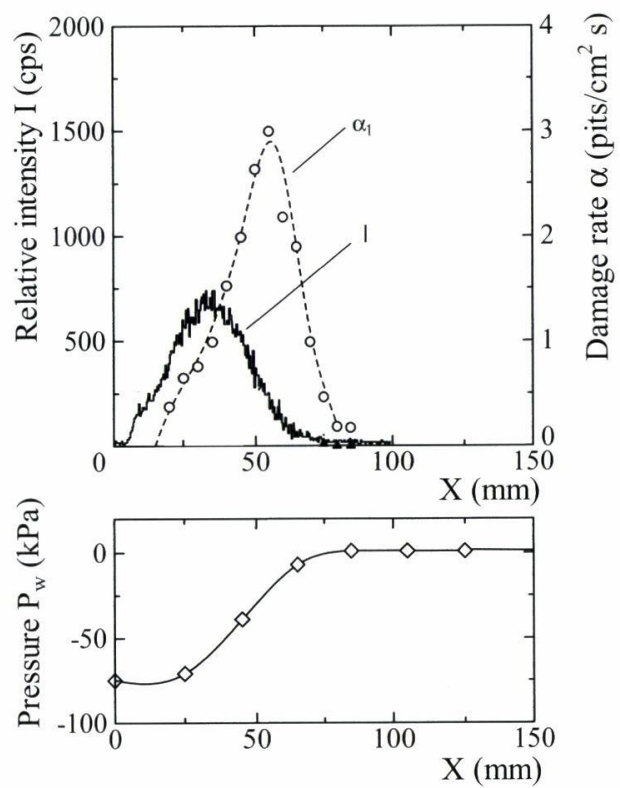

(b) $P_{I}=350 \mathrm{kPa}$

図8 (a), (b) 壊食速度と発光強度分布 

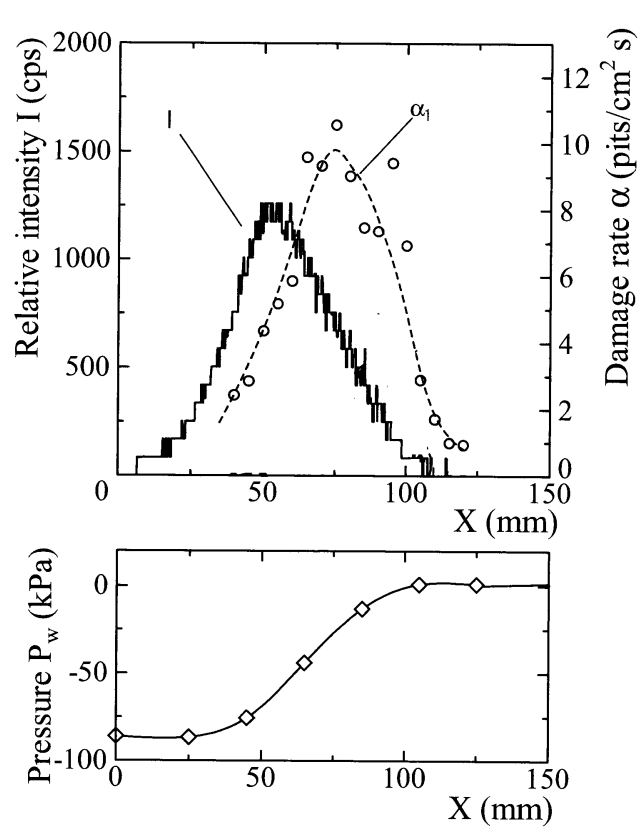

(c) $P_{I}=400 \mathrm{kPa}$
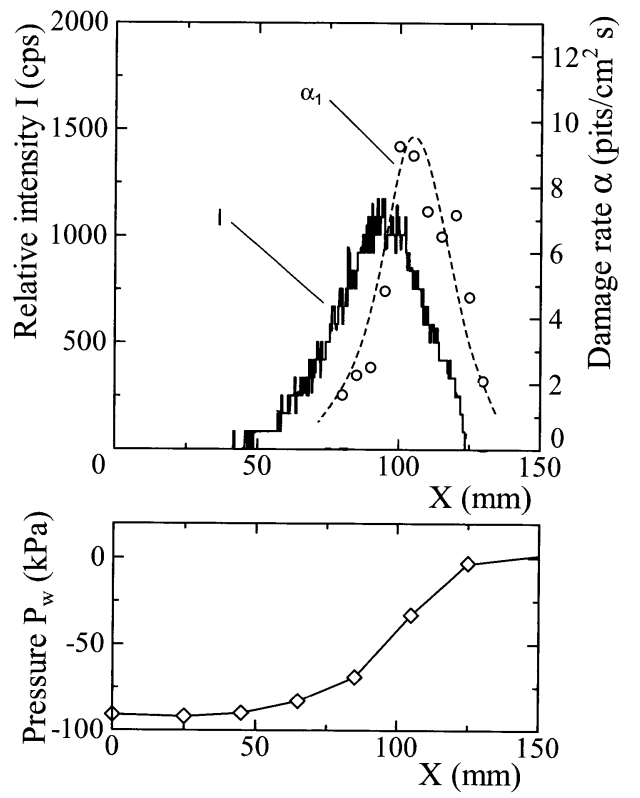

(d) $\quad P_{I}=450 \mathrm{kPa}$

図 8 (c), (d) 壊食速度と発光強度分布

生じる訳で, 微視的メカニズムの差異によると考えら れる. 発光強度分布と壊食速度分布は必ずしも一致し ないが，いずれも圧力回復領域内にあり，かつ，加圧 力が高くなるほど，互いに近づく傾向がある.

最大発光強度 $I_{\max }$ と最大壊食速度 $\alpha_{\max }$ の関係を図 9 に示す. 明らかに両者の間には正の相関が見られる. 加圧力 $P_{1}=300 \sim 500 \mathrm{kPa}$ の条件で得た $I_{\max }$ と $\alpha_{\text {max }}$ の関 係はほぼ,

$$
\alpha_{1 \max } \propto I_{\max }{ }^{1.4}
$$

である. 一般にピット法の壊食速度は壊食の初期段階 の值であり，実験条件による影響を受けやすいが，水

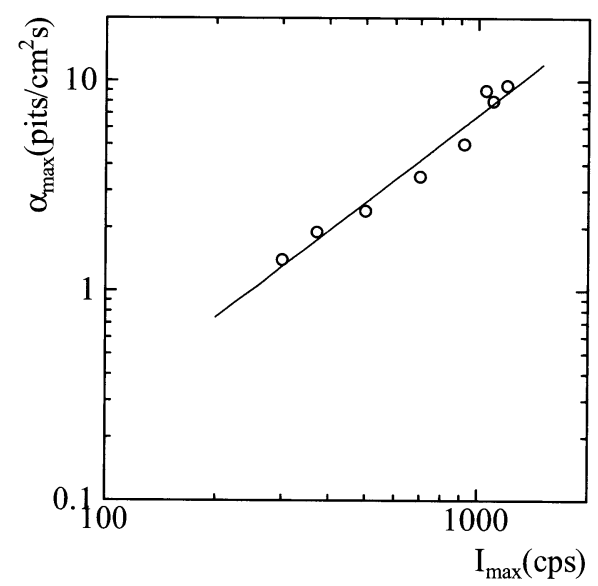

図 9 最大発光強度と最大壊食速度の関係

中翼まわりに発生するシートキャビテーションの場合 (21) の指数 $0.8 \sim 1.5$ とおおよそ一致している.

\section{5. 円柱周りのキャビテーション}

流体機器を想定したある程度複雑な流れ場を作り， 発光と壊食の関係を調べることにした. キャビテーシ ヨン試験が比較的容易である三次元流れの例として, 半円管に設置した円柱周りに発生するキャビテーショ ンを取り上げることにした.

図 10 に試験区間の概略を示寸。試験流路は内径 $D=26 \mathrm{~mm}$ の透明アクリル管中心に平板台を設置し, 半 円管とした．平板台には試験物体を取り付けられるよ うになっている。試験円柱は直径 $d_{c}=12 \mathrm{~mm}$, 高さ $h_{c}=8 \mathrm{~mm}$ である. 半円管とした理由としては, 物体周 りの流れがどの方向からも観測しやすいこと，壊食が 平板上に発生することで両者の関係が調べやすいこと である.

図 11 に円柱のキャビテーション流および発光の様 子を示す. 図 11 (a) はキャビテーション流の写真, 図 11 (b) はキャビテーション発光の写真であり，上 側の写真は管上面から，下側の写真は管側面から撮影

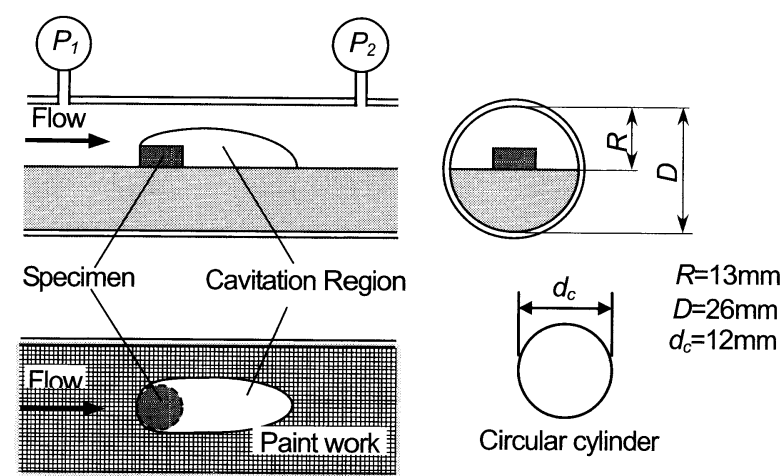

図 10 円柱周りのキャビテーション試験 


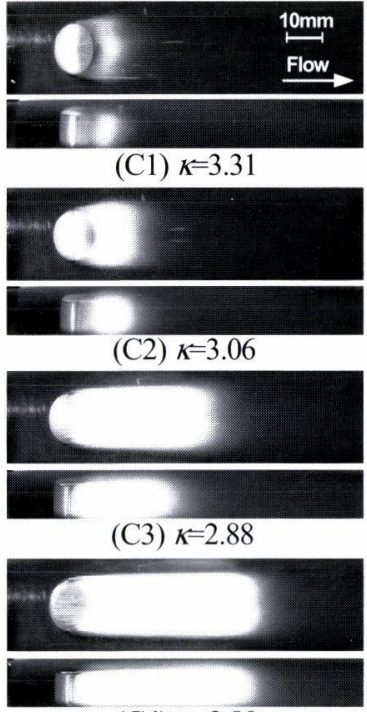

(C4) $k=2.80$

(a) Cavitation flow
(C2) $k=3.06$

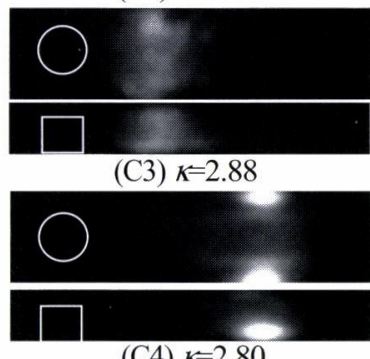

(b) Luminescence

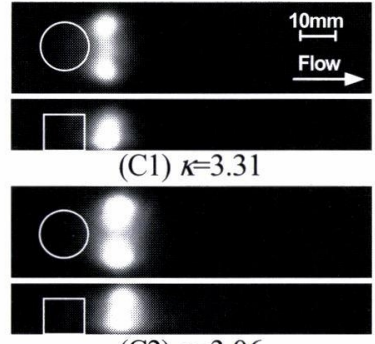

図 11 円柱周りのキャビテーション気泡と発光 $V=12 \mathrm{~m} / \mathrm{s}, R e=143000$

したものである. 円柱周りに生じるキャビテーション 流の場合, キャビテーションはまず試験物体上端の前 縁部および側面から発生し, キャビテーション係数の 減少とともにキャビテーション領域は下流側一と広が る. 図 11（a）の C1，C2 では渦, クラウドキャビテ ーションが支配的であり，C3，C4 ではシートキャビ テーションが支配的である. また, C3 では側壁近傍に サイドウォールキャビテーションが発生している.

円柱におけるキャビテーション発光の写真より, 発光 はいずれも物体後方で生じ，そのパターンは 1 対の対 称渦のようになっていることがわかる，発光領域は， キャビテーション係数が減少すると下流側へ移行した. クラウドキャビテーションのときの発光パターンは明 確で, 強度も強いが, シートキャビテーションのとき のパターンはやや不鮮明となり, 強度も弱い。しかし サイドウォールキャビテーションにおいてかなり強い 発光が生じていることがわかる.

図 12 に $V=12 \mathrm{~m} / \mathrm{s}$, 図 13 に $V=10 \mathrm{~m} / \mathrm{s}$ の流れに置いた 円柱に対寸るキャビテーション発光の強度分布を示寸。 $X$ は物体中心から下流に向かっての距離で, 発光強度 $I$ はフォトンカウンターで計測した管中心軸上の絶対 強度で, 補正なしの值をそのまま示したものである. したがって強度は相対值である。ここでの值は清水を 使用したもので, 可視化増光のためのキセノンガスの 混入は行なっていない，いずれの条件でも, 相対発光 強度分布は山形を示しており, ピーク発光強度 $I_{p}$ を持 っている.ピーク発光強度の位置 $X_{p}$ はキャビテーショ ン係数が減少寸ると下流側へ移行寸る. ピーク発光強 度はクラウドキャビテーション（ $\kappa$ = 3.0）のときはか

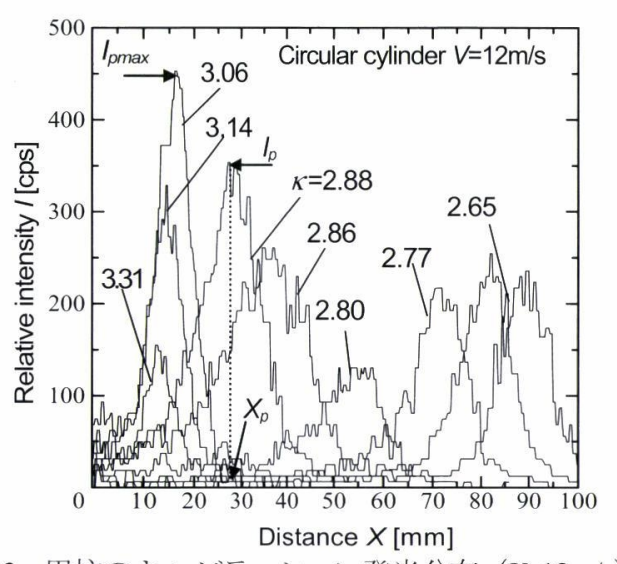

四 12 円柱のキャビテーション発光分布 $(V=12 \mathrm{~m} / \mathrm{s})$

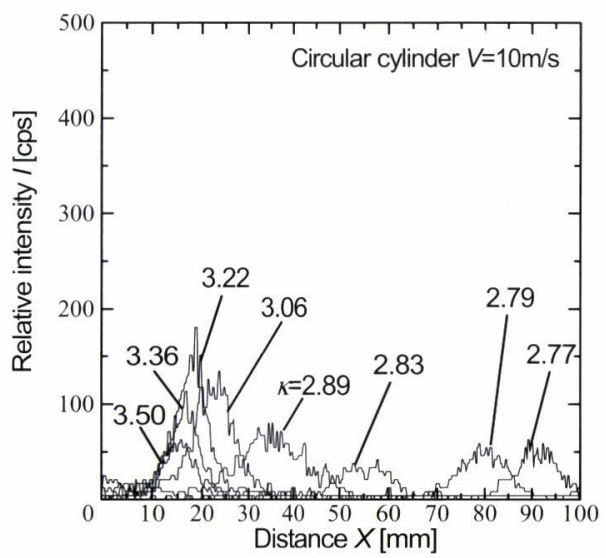

図 13 円柱のキャビテーション発光分布 $(V=10 \mathrm{~m} / \mathrm{s})$

なり大きく, シートキャビテーション $(\kappa=2.8)$ のと きは小さいことがわかる.

図 12 , および図 13 より流速が $V=12 \mathrm{~m} / \mathrm{s}$ から $V=10 \mathrm{~m} / \mathrm{s}$ へとわずかに減少しただけでも発光強度 $I$ は約 $1 / 2$ と大きく低下している。 この場合, 発光強度 $I$ は流速 $V$ の 3.5 4 乗に比例すること意味し, 流速に強く依 存していることがわかる. 水中翼の研究では流速のほ ぼ3 乗に比例している.しかしながら発光強度分布形 状にはあまり変化がない，

図 14 にピーク発光強度とキャビテーション係数の 関係を示寸.ピーク発光強度 $I_{p}$ は最大発光強度 $I_{p \max }$ で, キャビテーション係数 はは初生キャビテーション係数 $\kappa_{i}$ で無次元化し, 速度 $V=12 \mathrm{~m} / \mathrm{s}$ および $V=10 \mathrm{~m} / \mathrm{s}$ の場合 について整理した、Vが同一の場合，このような表示 にするとデータは固有の同一分布曲線上にのり， $\kappa$ $I_{\text {pmax }}$ 分布には相似性が見られることが分かる.

図 15 に円柱における発光パターンと塗装法による 壞食パターンの比較を示寸，各実験条件は図中に示す 通りである. 発光領域（上図）と壊食領域（下図）は よく類似しており, 発光強度の強、領域て壊食も強く 発生していることが確認できる．また，底面近傍の発 光が強いほど壊食も顕著である. 


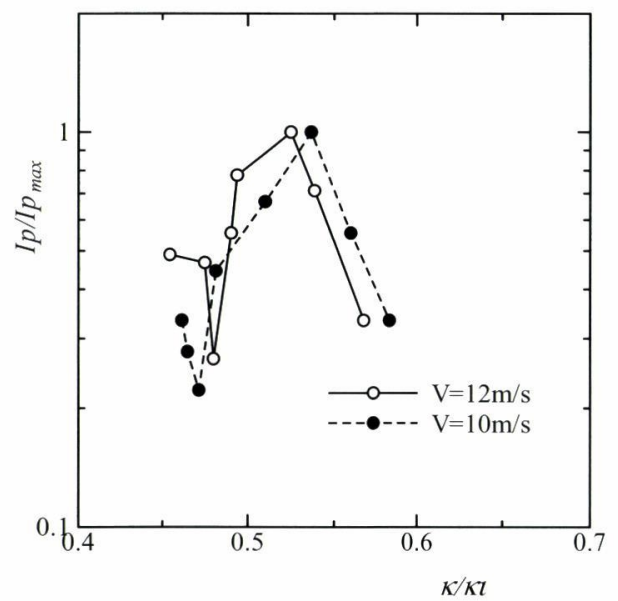

図 14 ピーク発光強度とキャビテーション 係数の関係

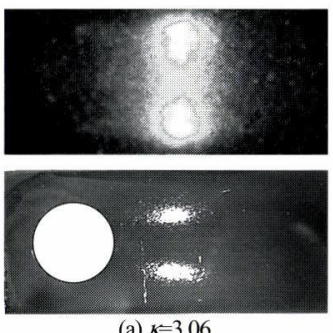

（発光領域）

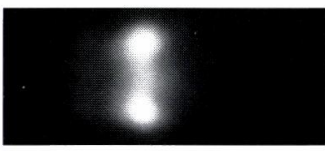

（発光領域）

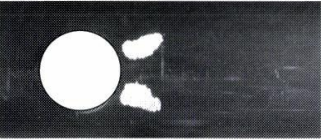

（壊食領域）

(b) $k=3.42$

図 15 円柱における発光パターンと塗装法による 壞食パターンの比較 $(V=12 \mathrm{~m} / \mathrm{s}, R e=143000)$

図 16 にピーク発光強度とその位置に置いた銅版を用 いて行った壊食速度（単位面積単位時間当たりの壊食 ピット発生数) $N_{p}$ の関係を示寸. 実験は主に発光の強 いクラウドキャビテーション領域で行った，両者には 相関関係が見られ，ほぼ式（2）で近似できた。

図 17 にを $12 \mathrm{~m} / \mathrm{s}$ 一定とし, キャビテーション係 数比内 $\kappa_{i}$ に対寸る発光強度と壊食速度の変化を示寸. 発光強度と壊食ピット発生数はそれぞれの最大值で無 次元化してある. 図中の破線は二次元円柱に対寸る損 失質量速度の実験結果 ${ }^{(22)}$ である. キャビテーション係 数の変化に対して発光強度と壊食ピット発生数は山形 の変化を示し,互いに類似したパターンを示している. 特に, 発光ピーク位置より右側でよく似ている. 右側 は渦, クラウドキャビテーションであり, 左側は本装 置の場合, 流路が狭いためにシートキャビテーション になり易くなっている. 物体形状や流れ場が変わるも のの, 全体の傾向はよく一致することから両者の相関

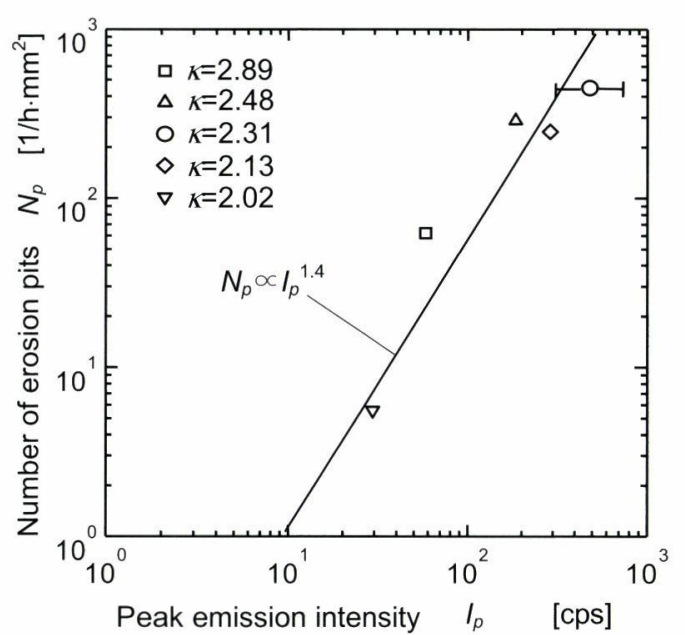

図 16 ピーク発光強度と壊食速度の関係

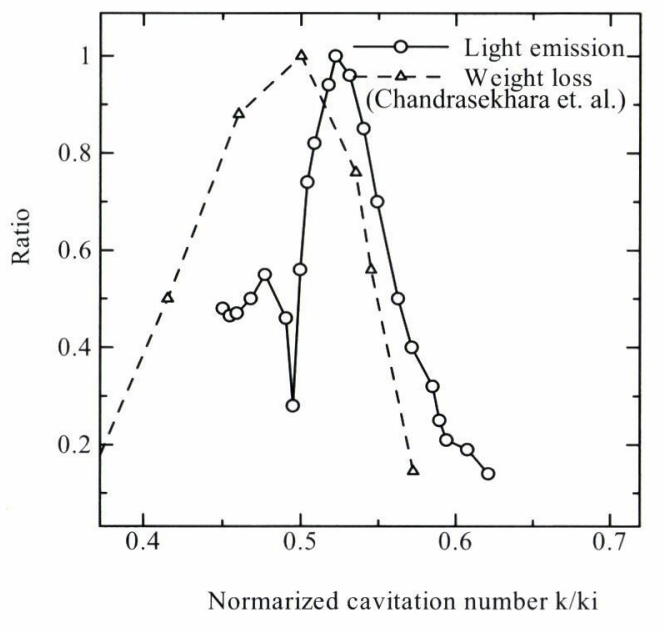

図 17 発光強度と壊食速度の変化

性はかなり強いものと考えられる.

\section{6. まとめ}

2004 年に発生した美浜原発のオリフィス流量計破 損事故は，本論で示した実験とよく似ていると考えら れる. キャビテーション発光を起こすような環境はク ラウドキャビテーションのような壊食性の強い気泡が 存在することを示唆している.

複雑な流体機械の開発段階の模型実験で発光計測を 壊食実験計画に組み入れることで実験の効率化が期待 できると考えられる.

\section{参考文献}

(1) Fortes-Patella, R. and Reboud,J. L., A new approach to evaluate the cavitation erosion power, Transactions of the ASME Journal of Fluids 
Engineering, 120 (1998), 335-344.

(2) 田部井・白井, 円管内オリフィス流のキャビテー ション発光特性（増光物質による影響）日本機械 学会論文集, B62-597(1996), 84-89.

(3) 田部井・白井・本島, キセノンを含むキャビテー ション気泡の非平衡プラズマ理論, 日本機械学会 論集, B65-633 (1998), 1652-1657.

(4) 田部井・白井・高草木, フォトンカティング法に よる円管内オリフィス流のキャビテーション発光 領域の可視化, 日本機械学会論文集, B59-568 (1993), 3720-3725.

(5) Tabei, K. and Shirai, H., Visualization of cavitation light emission and bubble distribution in an orifice flow by a computerized tomography, PSFVIP-3, F3485 (2001), 75-76, Hawaii.

(6) 田部井・白井・益子・村・高草木 $\cdot$ 蜂須賀, オリフ イスキャビテーション発光流中の銅ロッドの壊食, 日本機械学会論文集 B69-677，(2003)，18-24

(7) K. Tabei, Y. Fukuda and Y.Araki, Visualization of Feeble cavitation light emission region generated around a columnar object, The $8^{\mathrm{TH}}$ Asian symposium on visualization, (2005) Chiangmai.

（8）服部・前田，ロジスティック解析に基づくキャビ テーション挙動の定式化, 日本機械学会論文集, A70-691, (2004), 510-515.

(9) 加藤洋治, 新版キャビテーション(1999), 199-203, 梖書店

(10) Greenspan, H. P. and Nadim, A., On sonoluminescence of an oscillating gas bubble, Phys. Fluids, A 5-4 (1993) 1065-1067.

(11) Bernstein, L.S. and Zakin, M. R., Confined electron model for single-bubble sonoluminescense, J. Phys. Chem., 99-40 (1995), 14619-14627.

(12) Didenko,Y.T., MacNamara III and Suslic,K.S., Hot spot conditions during cavitation in water, J. .Am. Chem. Soc. 121 (1999) 5817-5818.

(13) Yasui, K., Alternative model of single-bubble sonoluminescence, Physical Review E, 56-6, (1997) 6750-6760

(14) Yasu, K, Effect of volatile solutes on sonoluminescence, J.Chem.Phys. 116, (2002), 2945-2954.

(15) Gong, C. and Hart, D.P., Interactions of bubble dynamics and chemistry in cavitation bubbles induced by ultrasound, Proc. 3rd ASME/JSME Fluids Engineering Conference, FEDSM99-6758 (1999), 1-5.

(16) van der Meulen, J.H.J., The use of luminescence as a measure of hydrodynamic cavitation activity, ASME Cavitation and Multiphase Flow Forum, (1983), 51-53, Houston.

(17) van der Meulen, J. H. J., The relation between noise and luminescence from cavitation on a hydrofoil, ASME FED, 25 (1985), 149-159.

(18) van der Meulen, J. H. J., Nakasima,Y, A study of the relationship between type of cavitation, erosion and luminescence, I Mech E, C192/83 (1983), 13-19.

(19) Leighton, T.G. ,Farhat,M.,Field,J.E., and Avellan,F.,
Cavitation luminescence from flow over a hydrofoil in a cavitation tunnel, J. Fluid Mech. 480 (2003), 43-60.

(20) 根岸勝雄 - 高木堅志郎, 超音波技術, 東京出版会, (1984) 103-104

(21) van der Meulen, J.H.J, Some physical phenomena associated with cavitation, Theoretical and applied Mechanics Elsevier science Publishers North-Holland (1989) 369-387.

(22) Chandrasekhara, D. V., Syamala Rao, B.C., Effect of pressure on the length of cavity and cavitation damage behind circular cylinders in a venturi, Transactions of the ASME Journal of Fluids Engineering, 95 Ser I, Issue 2 (1973) 197-206. 